\title{
Multimarker Gene Analysis of Circulating Tumor Cells in Pancreatic Cancer Patients: A Feasibility Study
}

\author{
Andreia de Albuquerque ${ }^{a, b} \quad$ Ilja Kubisch ${ }^{d}$ Georg Breier ${ }^{a} \quad$ Gudrun Stamminger $^{c}$ \\ Nikos Fersis ${ }^{\mathrm{e}}$ Astrid Eichler $^{\mathrm{f}}$ Sepp Kaul ${ }^{\mathrm{b}} \quad$ Ulrich Stölzel $^{\mathrm{d}}$ \\ ${ }^{a}$ Department of Pathology, Technische Universität Dresden, Dresden, ${ }^{b}$ Department of Molecular Biology at the \\ ${ }^{\mathrm{C}}$ Zentrum für Diagnostik, Departments of ${ }^{\mathrm{d}}$ Internal Medicine, and ${ }^{\mathrm{e}} \mathrm{Gynaecology}$ and Obstetrics, Klinikum \\ Chemnitz, Chemnitz, and ${ }^{\mathrm{f} D e p a r t m e n t ~ o f ~ H e m a t o l o g y, ~ G o e t h e ~ U n i v e r s i t a ̈ t ~ F r a n k f u r t, ~ F r a n k f u r t, ~ G e r m a n y ~}$
}

\section{Key Words}

Circulating tumor cells · Pancreatic cancer - Reverse

transcriptase real-time polymerase chain reaction

\begin{abstract}
Objective: The aim of this study was to develop an immunomagnetic/real-time reverse transcriptase polymerase chain reaction (RT-PCR) assay and assess its clinical value for the molecular detection of circulating tumor cells (CTCS) in peripheral blood of pancreatic cancer patients. Methods: The presence of CTCs was evaluated in 34 pancreatic cancer patients before systemic therapy and in 40 healthy controls, through immunomagnetic enrichment, using the antibodies BM7 and VU1D9 [targeting mucin 1 and epithelial cell adhesion molecule (EpCAM), respectively], followed by realtime RT-PCR analysis of the genes KRT19, MUC1, EPCAM, CEACAM5 and BIRC5. Results: The developed assay showed high specificity, as none of the healthy controls were found to be positive for the multimarker gene panel. CTCs were detected in $47.1 \%$ of the pancreatic cancer patients before the beginning of systemic treatment. Shorter median progression-free survival (PFS) was observed for patients who had at least one detectable tumor-associated transcript, compared with patients who were CTC negative. Median PFS
\end{abstract}

time was 66.0 days [95\% confidence interval (CI) 44.8-87.2] for patients with baseline CTC positivity and 138.0 days ( $95 \%$ Cl 124.1-151.9) for CTC-negative patients ( $p=0.01$, log-rank test). Conclusion: Our results suggest that in addition to the current prognostic methods, CTC analysis represents a potential complementary tool for prediction of outcome in pancreatic cancer patients.

Copyright $\odot 2012$ S. Karger AG, Basel

\section{Introduction}

Pancreatic cancer is the 10th most commonly diagnosed cancer and has the highest mortality rate, as $96 \%$ of the patients diagnosed with this malignancy die within the first 5 years [1]. Pancreatic cancer lacks early symptoms and is, as a consequence, often diagnosed at a late stage when disease has spread to neighboring tissues, beyond the treatment window of curative resection [2]. The inaccessibility of the pancreas further limits the possibility of surgical removal, and the aggressive nature of the tumor leads to a rapid progression that is strongly resistant to chemotherapy [3]. Moreover, the conventional prognostic indicators to predict patient outcome are often imperfect, owing mainly to tumor plasticity and sub-

\section{KARGER}

Fax +4161306 1234 E-Mail karger@karger.ch www.karger.com

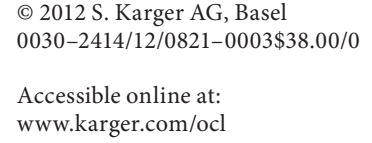

Andreia de Albuquerque

Zentrum für Diagnostik am Klinikum Chemnitz

Flemmingstrasse 2

DE-09116 Chemnitz (Germany)

Tel. +49371333 34523, E-Mail Andreia.de.Albuquerque@gmail.com 
jective assessment criteria [4]. Therefore, there is an urgent need for the establishment of new sensitive prognostic methods capable of identifying patients with a worse prognosis or those destined to progress quickly.

During recent years, the analysis of circulating tumor cells (CTCs) has become a promising diagnostic tool in oncology. However, although the prognostic value of CTCs has been extensively studied in breast, colorectal and prostate cancer [5-11], its role in pancreatic cancer is still poorly investigated. To date, only a few studies have assessed CTCs in peripheral blood (PB) of pancreatic cancer patients, with most of the published work reporting small cohorts, low CTC positivity rates and contradictory results [12].

In the present study, we have employed immunomagnetic enrichment and real-time reverse transcriptase polymerase chain reaction (RT-PCR) as the methodological basis for the development of a CTC detection method. Our goal was to create an accurate assay that would improve the detection of CTCs in $\mathrm{PB}$ of pancreatic cancer patients and, at the same time, avoid false-positive results. Moreover, we aimed to evaluate whether CTC detection could be used as a tool to refine prognosis in pancreatic cancer management.

\section{Patients and Methods}

\section{Patient Selection and PB Sampling}

Written informed consent was obtained from all participants, and the study was approved by the local medical ethical committee. The principal inclusion criteria were as follows: patients with histologically and radiographically proven pancreatic adenocarcinoma, initiating any first- or second-line systemic therapy. $\mathrm{Pa}$ tients with a history of previous malignancy and patients with active infection were excluded.

Whole blood samples $(10.0 \mathrm{ml})$ were collected into EDTA tubes from all subjects before therapy (Sarstedt AG \& Co., Nümbrecht, Germany), and CTCs were isolated within $4 \mathrm{~h}$ of specimen collection. A group of healthy, anonymous control subjects, who were randomly selected from hospital staff, were asked to participate in the study, and blood sampling was performed as described above.

\section{Patient Follow-Up}

Patients underwent chemotherapy as appropriate for their diagnosis and disease evaluation by their medical oncologist according to the institutional guidelines. The evaluation included a physical examination, a complete blood count, blood chemical tests, screening for serum tumor markers, radiography, computed tomographic scan and magnetic resonance imaging according to tumor type and stage. The planned reevaluation for patients with metastatic disease was performed every 3 months. Response was evaluated according to the clinical criteria codified by the Response Evaluation Criteria in Solid Tumors [13] by a team of med- ical oncologists and radiologists. Each disease assessment was classified as a complete response, partial response, stable disease or progressive disease. The primary end point for metastatic patients was time to progression. For response to therapy in the metastatic setting, the favorable group was defined as having nonprogressive disease (complete response, partial response and stable disease categories), and the unfavorable group was defined as those patients who suffered progressive disease or death.

\section{CTC Isolation from Blood Samples}

CTCs were isolated from PB using $200 \mu \mathrm{l}$ of BM7/VU1D9 antibodies coupled directly to immunomagnetic $4-\mu \mathrm{m}$ Dynabeads ${ }^{\circledR}$ (Invitrogen, Karlsruhe, Germany). Beads were incubated with the $\mathrm{PB}$ on a low-speed rotating device for $20 \mathrm{~min}$ at room temperature, after which labeled cells were separated using an external magnetic particle concentrator. The bead fraction was washed 5 times with phosphate-buffered salt solution, and the retained mucin 1-positive and/or epithelial cell adhesion molecule (EpCAM)positive cells were lysed in $400 \mu \mathrm{l}$ of Tris-HCl lysis buffer (included in the Dynabeads mRNA Direct ${ }^{\mathrm{TM}}$ Kit, Invitrogen) and stored at $-85^{\circ} \mathrm{C}$ until $\mathrm{mRNA}$ isolation and $\mathrm{cDNA}$ synthesis.

mRNA Isolation and cDNA Synthesis

mRNA isolation from the lysed enriched cells was performed with the Dynabeads mRNA Direct Kit according to the manufacturer's instructions. Sensiscript ${ }^{\circledR}$ Reverse Transcriptase (Qiagen, Hilden, Germany), recommended for first-strand cDNA synthesis using $<50 \mathrm{ng}$ RNA, was used for reverse transcription of the isolated and purified mRNA in combination with the Dynabeads oligo(dT $)_{25}$ (Invitrogen), according to the manufacturer's guidelines. Reverse transcription was performed in $0.5 \mu \mathrm{l}$ of $\mathrm{RNasin}^{\circledR}$ Ribonuclease Inhibitor (40 U/ $\mu$ l; Promega, Mannheim, Germany), $4 \mu$ l of reverse transcriptase buffer, $4 \mu$ l of dNTPs ( 5 mM each) and $2 \mu \mathrm{l}$ of Sensiscript Reverse Transcriptase and synthesized in a thermocycler under the following conditions: $60 \mathrm{~min}$ at $37^{\circ} \mathrm{C}$ followed by $5 \mathrm{~min}$ at $93^{\circ} \mathrm{C}$. The resulting $40 \mu \mathrm{l}$ of cDNA was stored at $-20^{\circ} \mathrm{C}$ until further use.

\section{Multimarker Real-Time PCR Analysis}

Reverse transcription resulted in CDNA which was the template for tumor cell detection and characterization by real-time PCR. The analysis of tumor-associated mRNA isolated from CTCs was performed for 5 tumor-associated transcripts: KRT19, MUC1, EPCAM, CEACAM5 and BIRC5. Primers were selected using the Universal ProbeLibrary ${ }^{\circledR}$ system, and their sequences can be seen in table 1 . The selected primers were designed to be intron spanning (exon specific) so as to eliminate reactivity with genomic DNA. The amplification of ACTB (primers: forward, $5^{\prime}$ GAAGAGCCAAGGACAGGTAC-3'; reverse, 5'-CAACTTCATCCACGTTCACC- $3^{\prime}$ ) served as a reference internal control and was used to verify the integrity of the RNA and the quality of the samples. PCR amplifications were performed on the Rotor-Gene 3000 in a total volume of $25 \mu$ l. Each reaction contained $12.5 \mu \mathrm{l}$ of the reaction buffer MESA FAST qPCR MasterMix Plus for SYBR $^{\circledR}$ assay (Eurogentec, Cologne, Germany), including dNTPs (together with dUTP), MeteorTaq DNA polymerase, $\mathrm{MgCl}_{2}$ (4 mM final concentration), SYBR Green I and stabilizers, $0.1 \mu \mathrm{l}$ of each primer $(100 \mathrm{pmol} / \mu \mathrm{l}), 2 \mu \mathrm{l}$ of $\mathrm{cDNA}$ and $10.3 \mu \mathrm{l}$ of RNasefree $\mathrm{H}_{2} \mathrm{O}$. The thermal profile used for real-time PCR was as follows: after a 5 -min denaturation at $95^{\circ} \mathrm{C}, 40$ cycles were carried 
Table 1. Intron-spanning primer pairs for each selected gene

\begin{tabular}{|c|c|c|c|c|c|}
\hline \multirow{2}{*}{$\begin{array}{l}\text { Marker } \\
\text { KRT19 }\end{array}$} & \multirow{2}{*}{$\begin{array}{l}\text { NM reference } \\
\text { NM_002276.2 }\end{array}$} & \multicolumn{2}{|c|}{ Primer sequence } & \multirow{2}{*}{$\begin{array}{l}\text { Location } \\
525-545, \text { exon } 1 \\
650-630, \text { exon } 2 / 3\end{array}$} & \multirow{2}{*}{$\frac{\text { Product size, bp }}{126}$} \\
\hline & & $\begin{array}{l}\text { forward } \\
\text { reverse }\end{array}$ & $\begin{array}{l}\text { GCCACTACTACACGACCATCC } \\
\text { CAAACTTGGTTCGGAAGTCAT }\end{array}$ & & \\
\hline MUC1 & NM_002456.4 & $\begin{array}{l}\text { forward } \\
\text { reverse }\end{array}$ & $\begin{array}{l}\text { TCGTAGCCCCTATGAGAAGG } \\
\text { CCACTGCTGGGTTTGTGTAA }\end{array}$ & $\begin{array}{l}795-814, \text { exon } 7 / 8 \\
865-846, \text { exon } 8\end{array}$ & 71 \\
\hline EPCAM & NM_002354.2 & $\begin{array}{l}\text { forward } \\
\text { reverse }\end{array}$ & $\begin{array}{l}\text { CGTCAATGCCAGTGTACTTCA } \\
\text { TTTCTGCCTTCATCACCAAA }\end{array}$ & $\begin{array}{l}448-508, \text { exon } 2 \\
575-553 \text {, exon } 3\end{array}$ & 88 \\
\hline CEACAM5 & NM_004363.2 & $\begin{array}{l}\text { forward } \\
\text { reverse }\end{array}$ & $\begin{array}{l}\text { ACCACAGTCACGACGATCAC } \\
\text { CTCCACGGGGTTGGAGTT }\end{array}$ & $\begin{array}{l}1052-1071, \text { exon } 4 \\
1129-1112 \text {, exon } 5\end{array}$ & 78 \\
\hline BIRC5 & NM_001168.2 & $\begin{array}{l}\text { forward } \\
\text { reverse }\end{array}$ & $\begin{array}{l}\text { GCCCAGTGTTTCTTCTGCTT } \\
\text { CCGGACGAATGCTTTTTATG }\end{array}$ & $\begin{array}{l}284-303, \text { exon } 2 \\
369-350 \text {, exon } 3\end{array}$ & 86 \\
\hline
\end{tabular}

out with denaturation at $95^{\circ} \mathrm{C}$ for $5 \mathrm{~s}$, annealing at $59^{\circ} \mathrm{C}$ for $20 \mathrm{~s}$ and extension at $72^{\circ} \mathrm{C}$ for $12 \mathrm{~s}$.

PCR efficiency, linearity and sensitivity for each gene were validated with a standard curve constructed from a simultaneously run serially diluted cDNA pool of human PB lymphocytes (PBLs) and the tumor cell line $\mathrm{ZE}$, which expresses all the gene markers analyzed in this assay. Negative controls included samples without reverse transcriptase and samples in which cDNA was replaced with genomic DNA. All values were obtained from the quantitative cycle $(\mathrm{Cq})$ at which the increase in SYBR green fluorescent signal associated with an exponential increase in PCR products reached the fixed threshold value of 0.25 .

Random PCRs were analyzed by gel electrophoresis in order to determine the specificity of the assay and ensure that with the PCR conditions and the different primer sets used, the product of the expected size was amplified.

\section{Data Analysis}

Taking into consideration all the limitations presented by relative and absolute quantification strategies, we used real-time RTPCR to detect the presence of a gene rather than to quantify it accurately. This approach is referred to as qualitative RT-PCR. However, in order to obtain an accurate yes/no answer, information about the analytical sensitivity of the real-time RT-PCR assay must be determined [14]. In the present study, we adopted the approach proposed by Caraguel et al. [15]. According to these authors, the analytical sensitivity of PCR, also referred to as the lower limit of detection, is defined as the minimum concentration of analyte detected at which $50 \%$ of the tested samples are positive and fit within the linear dynamic range of the reaction. Therefore, to demonstrate that the assay detects at least $50 \%$ of samples at a specified concentration with $95 \%$ confidence, a standard curve needs to be constructed and 5 replicates per dilution must be tested. The analytical sensitivity is then estimated as the last serial linear concentration that yielded positives in all 5 replicates, meaning that the $95 \%$ confidence interval (CI) for the probability of testing positive is $47.8-100 \%$. The corresponding Cq value obtained as the lower limit of detection for each gene is selected as the analytical cutoff. Any Cq value above this defined limit is considered not reliable. In the present study, serial 10-fold dilutions of a cDNA pool of human PBLs and ZE tumor cells were used to construct the standard curves.

\section{Statistical Analysis}

The linearity, efficiency and analytical sensitivity of the realtime RT-PCR assay were assessed by linear regression analysis. Standard curves were constructed for each marker, and from the equation obtained after regression analysis, the following parameters were determined: sensitivity, given by the y intercept; linearity, expressed as the correlation coefficient $\left(\mathrm{R}^{2}\right)$, and efficiency of the assay, determined by the slope of the log-linear phase of the amplification reaction.

The clinical utility of CTC detection in pancreatic cancer patients was assessed by means of survival analysis. Progressionfree survival (PFS) was defined as the time between the baseline CTC assessment (the initiation of treatment) and the documentation of first radiographic disease progression or death. Patients who were alive and progression free at the time of analysis were censored using the time between the baseline CTC assessment and their most recent follow-up evaluations. PFS in CTC-positive and CTC-negative groups was compared with the Kaplan-Meier method, and differences were tested with the log-rank test. Potential correlations between CTC findings and the clinicopathological characteristics of the patients were tested using either a $\chi^{2}$ test or Fisher's exact test.

A $p$ value of $<0.05$ was considered to be statistically significant. All analyses were carried out using SPSS (version 17.0, SPSS, Chicago, Ill., USA).

\section{Results}

Validation of the Multimarker Panel for CTC

Detection

The specificity of the real-time RT-PCR products was analyzed by high-resolution gel electrophoresis. Sharply defined bands of the correct size (76 bp for ACTB, $126 \mathrm{bp}$ for KRT19, 71 bp for MUC1, 88 bp for EPCAM, 78 bp for 

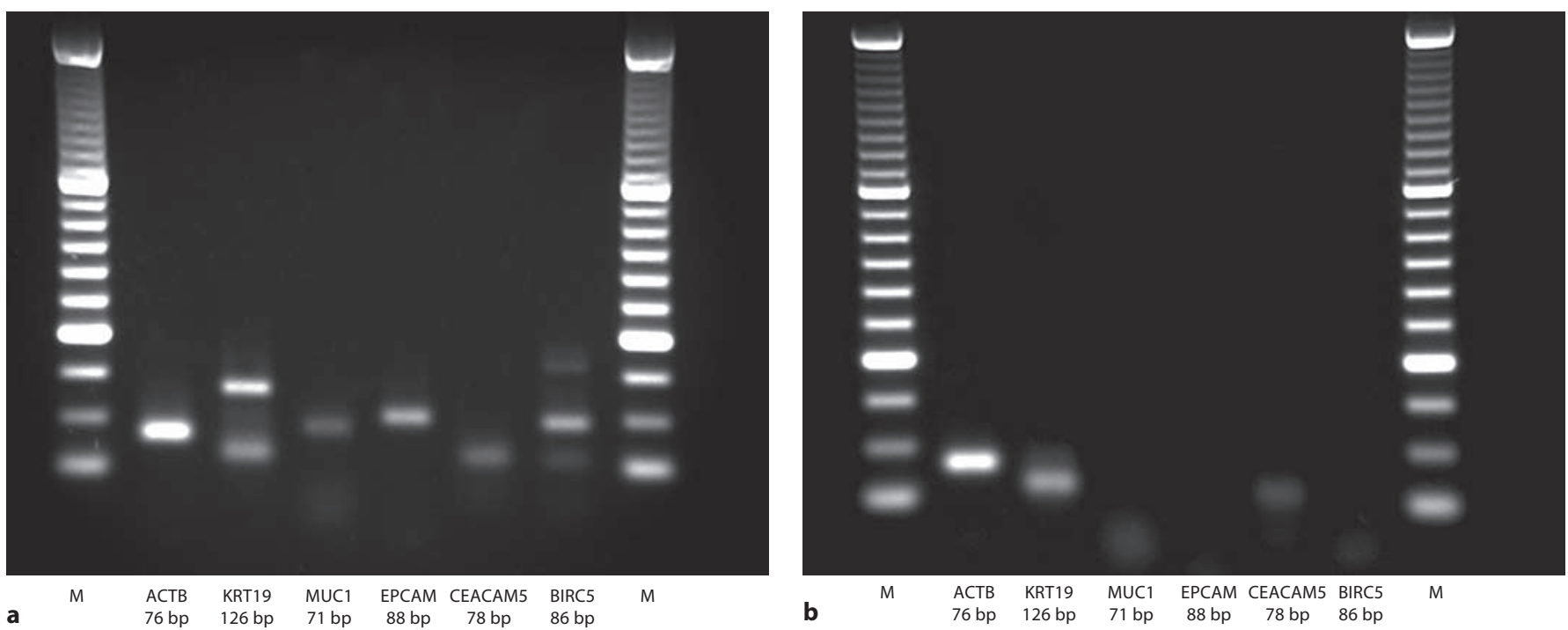

Fig. 1. Electrophoresis gel analysis of representative RT-PCR results for a CTC-positive pancreatic cancer patient (a) and a CTC-negative pancreatic cancer patient (b). Lane M: 50-bp ladder DNA size marker (Fermentas, St. Leon-Rot, Germany).

CEACAM5 and 86 bp for BIRC5) were obtained for the PCR products of the analyzed genes (fig. 1), and primer dimers were found to be present in cDNA samples tested for KRT19 and BIRC5. Bands visible after electrophoresis were concordant with the real-time RT-PCR results obtained.

To determine the linearity, efficiency and analytical sensitivity of the multimarker real-time RT-PCR assay, we analyzed serial 10-fold dilutions of a cDNA pool of human PBLs and ZE tumor cells in 5 different experiments for the 5 tumor-associated transcripts KRT19, MUC1, EPCAM, CEACAM5 and BIRC5. Calibration curves from these data showed linearity over the entire quantification range ( $1-10^{4}$ tumor cells) and $\mathrm{R}^{2} \geq 0.99$ in all of the cases, indicating a precise log-linear relationship. The PCR efficiency for the multimarker panel, expressed as $\mathrm{E}=10^{-1 / \text { slope }}$, ranged from 96 to $104 \%$ (data not shown). The analytical sensitivity was estimated as the last serial linear concentration that yielded positives in all 5 replicates, and the corresponding Cq value was selected as the analytical cutoff. According to the results obtained, the analytical Cq cutoff, under which a sample was considered to be positive for the corresponding marker gene, was 36.0 for KRT19, 37.1 for $M U C 1,36.0$ for EPCAM, 37.8 for CEACAM5 and 35.0 for BIRC5.

\section{Sample Quality}

The assessment of sample quality and RNA integrity are critical steps in obtaining meaningful gene expression data. Working with low-quality RNA may strongly compromise the acquisition of reliable results. Therefore, experiments were performed in order to establish a threshold criterion that delineates the sample quality and integrity sufficient to yield reliable results.

Random samples were tested for the leukocyte marker CD45. Results revealed that in all the samples with an $A C T B$ Cq value $>30.0$, no CD45 amplification was found. This indicates that at $A C T B$ Cq values higher than 30.0, the RNA integrity is fully compromised. Therefore, a total of 6 healthy blood donor samples and 2 patient samples were excluded from this study because their ACTB Cq value was $>30.0$. Moreover, in order to evaluate falsepositive marker expression due to unspecific background levels of mononucleated cells, samples containing different concentrations of lymphocytes were tested for the multimarker panel. Real-time RT-PCR analysis of samples containing $10^{3}$ PBLs presented a mean ACTB Cq value of 26.2 (range 24.1-27.4) and showed no amplification of any of the marker genes used in the present study. On the other hand, in samples containing $10^{4}$ PBLs, unspecific amplification of the markers MUC1, EPCAM and $B I R C 5$ was found. These samples presented $A C T B$ Cq values ranging from 21.1 to 24.0. Therefore, in order to avoid 
false-positive results due to lymphocyte contamination, a total of 3 patient samples with ACTB Cq values below 24.0 were excluded from this study.

\section{Patient Characteristics}

Between April 2009 and June 2011, a total of 40 patients were enrolled, 34 of whom met the inclusion and exclusion criteria [5 patients had to be excluded due to poor sample quality (inadequate $A C T B \mathrm{Cq}$ value) and 1 patient was excluded due to a history of previous malignant disease]. During the median follow-up period of 380 days (range 61-789), evidence of disease progression was documented in 23 patients and death had occurred in 9 patients. Detailed clinicopathological characteristics of the patients are given in table 2 .

\section{CTCs at Baseline}

At baseline, $47.1 \%$ of patients showed amplification of at least one tumor-associated marker mRNA in their PB sample. Positivity rates for each individual marker were as follows: $20.6 \%$ for KRT19 and MUC1, $23.5 \%$ for EPCAM, $2.9 \%$ for CEACAM5 and $17.6 \%$ for BIRC5. A total of $20.6 \%$ of the patients were positive for more than one marker. No amplification of the marker genes was seen in the 40 healthy controls. Detailed baseline CTC results can be seen in table 3 .

\section{Correlation between CTCs and Clinicopathological}

\section{Features}

The presence of CTCs in the PB of pancreatic cancer patients at baseline did not correlate with gender, stage, tumor size, lymph nodes or metastasis. However, CTC positivity was slightly correlated with a higher histological tumor grading.

\section{Correlation between CTCs and PFS in Pancreatic \\ Cancer Patients}

The correlation between PFS and baseline CTC status in pancreatic cancer patients was compared with the Kaplan-Meier method, and differences were tested using the log-rank test. PFS was calculated for groups defined by the presence or absence of CTCs before initiating chemotherapy (fig. 2). Overall median PFS was 120.0 days (95\% CI 89.4-150.6), while shorter median PFS was observed for patients who had at least one detectable tumorassociated transcript, compared with patients who were CTC negative. Median PFS time was 66.0 days (95\% CI 44.8-87.2) for CTC-positive patients and 138.0 days ( $95 \%$ CI 124.1-151.9) for CTC-negative patients ( $\mathrm{p}=0.01, \log$ rank test).

CTCs in Pancreatic Cancer
Table 2. Clinicopathological characteristics of the pancreatic cancer patients

\begin{tabular}{|c|c|c|c|c|c|}
\hline \multirow[t]{2}{*}{ Variable } & & \multirow{2}{*}{$\begin{array}{l}\text { All } \\
\text { pancreatic } \\
\text { cancer } \\
\text { patients }\end{array}$} & \multicolumn{2}{|c|}{ CTCs } & \multirow[t]{2}{*}{$\mathrm{p}$ value } \\
\hline & & & $\begin{array}{l}\text { pos- } \\
\text { itive }\end{array}$ & $\begin{array}{l}\text { neg- } \\
\text { ative }\end{array}$ & \\
\hline \multicolumn{2}{|l|}{ Total patients, $\mathrm{n}$} & 34 & 16 & 18 & \\
\hline \multirow{2}{*}{$\begin{array}{l}\text { Age at study } \\
\text { entry, years }\end{array}$} & median & 66.9 & & & \\
\hline & range & $55-74$ & & & \\
\hline \multirow[t]{2}{*}{ Gender } & female & 14 & 6 & 8 & 0.738 \\
\hline & male & 20 & 10 & 10 & \\
\hline \multirow[t]{3}{*}{ Tumor stage } & II & 4 & 2 & 2 & 0.389 \\
\hline & III & 2 & 0 & 2 & \\
\hline & IV & 28 & 15 & 13 & \\
\hline \multirow[t]{3}{*}{ Tumor size } & $\mathrm{T} 2$ & 5 & 1 & 4 & 0.395 \\
\hline & T3 & 14 & 7 & 7 & \\
\hline & $\mathrm{T} 4$ & 15 & 8 & 7 & \\
\hline \multirow[t]{2}{*}{ Lymph nodes } & N1 & 4 & 1 & 3 & 0.791 \\
\hline & $\mathrm{N} 2$ & 30 & 15 & 15 & \\
\hline \multirow[t]{3}{*}{ Histology grade } & G2 & 24 & 8 & 16 & 0.042 \\
\hline & G3 & 9 & 7 & 2 & \\
\hline & G4 & 1 & 1 & 0 & \\
\hline \multirow[t]{2}{*}{ Metastasis } & yes & 28 & 14 & 14 & 0.660 \\
\hline & no & 6 & 2 & 4 & \\
\hline
\end{tabular}

In order to evaluate whether different marker combinations would also correlate with PFS, we calculated PFS for patients with different combinations of positive CTC markers, as follows: when only KRT19 was positive, $\mathrm{p}=$ 0.068 ; when only $M U C 1$ was positive, $\mathrm{p}=0.273$; when only EPCAM was positive, $\mathrm{p}=0.174$; when only CEACAM5 was positive, $\mathrm{p}=0.196$; when only BIRC5 was positive, $\mathrm{p}=0.044$; when $K R T 19$ or $M U C 1$ was positive, $\mathrm{p}=0.014$; when KRT19 or EPCAM was positive, $\mathrm{p}=0.042$; when $M U C 1$ or EPCAM was positive, $\mathrm{p}=0.051$, and when KRT19, MUC1 or EPCAM was positive, $\mathrm{p}=0.006$.

\section{Discussion}

To the best of our knowledge, here we report the first study using mucin 1- and EpCAM-based immunomagnetic enrichment, followed by real-time RT-PCR analysis of KRT19, MUC1, EPCAM, CEACAM5 and BIRC5, as a way to detect CTCs in $\mathrm{PB}$ of pancreatic cancer patients and to evaluate their prognostic effect.

Oncology 2012;82:3-10 
Table 3. Detailed CTC data for the analyzed pancreatic cancer patients and healthy blood donor controls

\begin{tabular}{|c|c|c|c|c|c|c|c|c|}
\hline \multirow{2}{*}{$\begin{array}{l}\mathrm{Pa}- \\
\text { tient } \\
\text { ID }\end{array}$} & \multirow{2}{*}{$\begin{array}{l}\text { Re- } \\
\text { sponse }\end{array}$} & \multirow{2}{*}{$\begin{array}{l}\text { CTC } \\
\text { e status }\end{array}$} & \multicolumn{6}{|c|}{ CTC Cq value cutoff } \\
\hline & & & $\begin{array}{l}\text { ACTB } \\
(24.0- \\
30.0)\end{array}$ & $\begin{aligned} & K R T 19 \\
- & (36.0)\end{aligned}$ & $\begin{array}{l}\text { MUC1 } \\
(37.1)\end{array}$ & $\begin{array}{l}\text { EPCAM } \\
(36.0)\end{array}$ & $\begin{array}{l}\text { CEACAM5 } \\
(37.8)\end{array}$ & $\begin{array}{l}\text { BIRC5 } \\
(35.0)\end{array}$ \\
\hline 66.1 & PD & $\mathrm{P}$ & 28.9 & 35.4 & 36.2 & 35.5 & n.s. & n.s. \\
\hline 76.2 & PD & $\mathrm{N}$ & 27.3 & n.s. & n.s. & n.s. & n.s. & n.s. \\
\hline 77.1 & $\mathrm{PD}$ & $\mathrm{N}$ & 26.3 & n.s. & n.s. & n.s. & n.s. & n.s. \\
\hline 113.1 & death & $\mathrm{P}$ & 29.3 & n.s. & n.s. & 33.1 & n.s. & 35.1 \\
\hline 136.2 & $\mathrm{PD}$ & $\mathrm{N}$ & 26.9 & n.s. & 39.1 & n.s. & n.s. & 35.8 \\
\hline 148.1 & PD & $\mathrm{N}$ & 27.8 & n.s. & 39.1 & n.s. & n.s. & n.s. \\
\hline 154.1 & PD & $\mathrm{N}$ & 29.2 & n.s. & n.s. & n.s. & n.s. & 35.7 \\
\hline 154.7 & PD & $\mathrm{N}$ & 29.3 & n.s. & n.s. & n.s. & n.s. & n.s. \\
\hline 167.1 & PD & $\mathrm{P}$ & 26.5 & n.s. & 36.3 & 34.1 & 36.9 & 34.9 \\
\hline 179.1.1 & $1 \mathrm{PD}$ & $\mathrm{P}$ & 28.5 & n.s. & n.s. & n.s. & n.s. & 33.9 \\
\hline 179.4 & $\mathrm{PD}$ & $\mathrm{N}$ & 27.4 & n.s. & n.s. & n.s. & n.s. & n.s. \\
\hline 203.1 & death & $\mathrm{P}$ & 28.1 & 33.6 & n.s. & 34.9 & n.s. & 35.9 \\
\hline 209.1 & $\mathrm{PD}$ & $\mathrm{N}$ & 27.6 & n.s. & n.s. & n.s. & n.s. & n.s. \\
\hline 210.1 & PD & $\mathrm{P}$ & 27.3 & 31.9 & n.s. & n.s. & n.s. & 34.5 \\
\hline 211.1 & $\mathrm{PD}$ & $\mathrm{N}$ & 28.4 & n.s. & 39.3 & n.s. & n.s. & 35.9 \\
\hline 231.1 & death & $\mathrm{P}$ & 27.5 & 35.8 & n.s. & n.s. & n.s. & n.s. \\
\hline 242.1 & death & $\mathrm{N}$ & 29.2 & n.s. & n.s. & n.s. & n.s. & n.s. \\
\hline 246.1 & death & $\mathrm{P}$ & 27.5 & 34.0 & n.s. & n.s. & n.s. & 35.6 \\
\hline 261.1 & death & $\mathrm{N}$ & 27.2 & n.s. & n.s. & 36.7 & n.s. & n.s. \\
\hline 262.1 & PD & $\mathrm{P}$ & 26.7 & n.s. & 34.7 & 33.3 & n.s. & 33.8 \\
\hline 267.1 & death & $\mathrm{N}$ & 28.2 & n.s. & n.s. & n.s. & n.s. & n.s. \\
\hline 275.1 & $\mathrm{PD}$ & $\mathrm{N}$ & 28.8 & n.s. & n.s. & n.s. & n.s. & n.s. \\
\hline 278.1 & death & $\mathrm{N}$ & 27.6 & n.s. & n.s. & n.s. & n.s. & n.s. \\
\hline 295.1 & $\mathrm{PD}$ & $\mathrm{P}$ & 25.6 & 34.7 & 35.0 & 34.2 & n.s. & n.s. \\
\hline 297.1 & PD & $\mathrm{N}$ & 28.4 & n.s. & n.s. & n.s. & n.s. & n.s. \\
\hline 298.1 & PD & $\mathrm{P}$ & 25.8 & n.s. & 35.0 & 34.0 & n.s. & 35.2 \\
\hline 299.1 & $\mathrm{PD}$ & $\mathrm{N}$ & 28.9 & n.s. & n.s. & n.s. & n.s. & n.s. \\
\hline 300.1 & death & $\mathrm{P}$ & 27.6 & n.s. & n.s. & 36.6 & n.s. & 34.8 \\
\hline 313.1 & $\mathrm{SD}$ & $\mathrm{N}$ & 28.9 & n.s. & n.s. & n.s. & n.s. & n.s. \\
\hline 330.1 & PD & $\mathrm{P}$ & 29.1 & 34.9 & n.s. & n.s. & n.s. & n.s. \\
\hline 345.1 & PD & $\mathrm{P}$ & 29.0 & n.s. & 37.0 & n.s. & n.s. & n.s. \\
\hline 356.1 & PD & $\mathrm{P}$ & 28.6 & n.s. & 35.7 & 36.9 & n.s. & n.s. \\
\hline 369.1 & SD & $\mathrm{P}$ & 27.8 & n.s. & n.s. & 35.0 & n.s. & 34.1 \\
\hline 211.8 & PD & $\mathrm{N}$ & 29.0 & n.s. & n.s. & n.s. & n.s. & n.s. \\
\hline $\begin{array}{l}\text { Healthy } \\
\text { donor }\end{array}$ & है⿴囗十⺝ & & $\begin{array}{l}28.6 \\
\pm 1.2\end{array}$ & n.s. & $\begin{array}{l}38.5 \\
\pm 0.6\end{array}$ & $\begin{array}{l}36.9 \\
\pm 0.8\end{array}$ & n.s. & $\begin{array}{l}35.7 \\
\pm 0.5\end{array}$ \\
\hline
\end{tabular}

In the healthy blood donor controls, 7 probes gave a positive signal for MUC1, 11 probes for EPCAM and 6 for BIRC5. The mean $\pm \mathrm{SD}$ values were calculated using only these probes. All the $\mathrm{Cq}$ values obtained in the healthy blood donor controls were under the defined CTC positivity cutoffs. PD = Progressive disease; $\mathrm{SD}=$ stable disease; $\mathrm{P}=$ positive $\mathrm{N}$ = negative; $\mathrm{n} . \mathrm{s}$. = no signal of the gene found during the 40 PCR cycles. ples.

${ }^{1} \mathrm{Cq}$ values represent the mean $\pm \mathrm{SD}$ of the 40 analyzed sam-

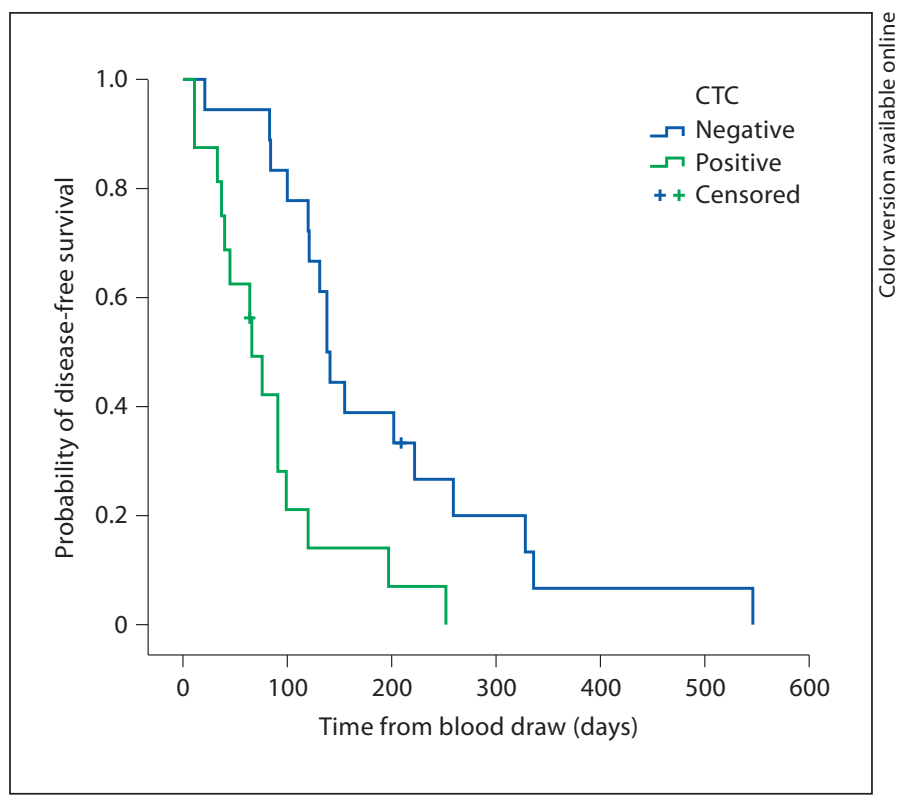

Fig. 2. PFS of pancreatic cancer patients with and without CTCs in $10 \mathrm{ml}$ of blood before therapy (CTC positivity is defined by positivity of at least one marker gene). In the present study, the time to event data was measured as the time between the baseline of the blood sampling for CTC analysis and the documentation of death or first tumor progression based on clinical and radiological studies. Patients who were alive and progression free at the time of analysis were censored using the time between the baseline CTC assessment and their most recent follow-up evaluations.

Despite the progress in pancreatic cancer treatment by the application of new chemoradioimmunotherapy protocols, the high recurrence rate is the most limiting factor for the improvement of patients' prognosis [16]. Current methods for the detection of recurrence or metastasis in the postoperative period rely on serum tumor markers $[17,18]$ and imaging modalities, which include radiography, computed tomography, magnetic resonance imaging and sonography $[19,20]$. However, these prognostic methods lack sensitivity and often do not allow for a more personalized approach to cancer treatment. Therefore, more sensitive staging methods capable of identifying patients who are destined to progress quickly or would benefit from more aggressive therapy are urgently needed for pancreatic cancer. Minimal residual disease caused by the spread of tumor cells into the circulation is discussed as a major reason for early metastases and local recurrence in pancreatic cancer. In recent years, only a few studies employing different methodologies for CTC isolation and detection [12, 21- 
27] have focused on the isolation and identification of CTCs in PB of pancreatic cancer patients, with some of them reporting contradictory results concerning the prognostic significance of CTCs. Soeth et al. [25] detected CK20-positive mRNA transcripts in the PB of 33.8\% $(52 / 154)$ of pancreatic cancer patients before operation and showed a statistically significant relationship between overall survival and the detection of CTCs in PB. Zhou et al. [26] reported that the combined analysis of C-MET, h-TERT, CK20 and CEA could detect CTCs in the PB blood of $100 \%(25 / 25)$ of pancreatic cancer patients before operation, radiotherapy and chemotherapy, with $100 \%$ specificity. Finally, Sergeant et al. [27] reported that no association was found between EpCAM positivity in $\mathrm{PB}$ of pancreatic ductal adenocarcinoma patients $(\mathrm{n}=48)$ and cancer-specific or disease-free survival; nor were significant correlations found between clinicopathological variables and perioperative EpCAM positivity.

In the present pilot study, we report the development of an immunomagnetic/real-time RT-PCR assay for CTC detection and characterization. Our data suggest that CTCs identified by this methodology can serve as a prognostic factor for pancreatic cancer patients beginning systemic treatment. The assay described herein provides a specific and sensitive method for isolation and identification of CTCs in PB of pancreatic cancer patients. CTCs were immunomagnetically enriched by coupling magnetic beads to the specific antibodies VU1D9 and BM7, with high affinity for the antigens EpCAM and mucin-1, respectively. By adding a second antibody targeting mucin-1, we have increased the chances for CTC isolation in comparison with solely EpCAM-based enrichment systems. All EpCAM-based assays share the same limitation, namely that EpCAM is expressed in most but not all tumors [28]. Several studies have found that EpCAM can be either upregulated or downregulated during cancer progression and metastasis $[29,30]$. Moreover, the real-time RT-PCR assay developed here showed high specificity, as none of the healthy controls were found to be positive for the multimarker gene panel. In addition, by preparing a standard curve for each gene, we determined the linearity, efficiency and analytical sensitivity of the assay. Subsequently, Cq cutoff values for each gene were created, so as to guarantee that no $\mathrm{Cq}$ value above the corresponding reliable analytical limit of detection of the assay was considered positive [15].

When applied in the clinic, the present assay revealed that $47.1 \%$ of pancreatic cancer patients showed amplifi- cation of at least one tumor-associated marker mRNA in their PB sample. Furthermore, our results demonstrate that the presence of at least one clearly detectable tumorassociated transcript in the PB of pancreatic cancer patients is a strong predictive factor for shorter PFS. Patients who were CTC positive before treatment had significantly reduced disease-free survival time compared with patients who were CTC negative. Moreover, CTC findings were also correlated with tumor grading. As expected, we observed that the CTC detection rate was significantly increased when a multimarker panel was applied compared with the results obtained using single markers. Metastatic tumors are particularly heterogeneous, and therefore, the combination of marker genes can compensate for variations in individual marker expression, increasing the chances of CTC detection [31]. Moreover, multimarker analysis of CTCs allows for characterization of these malignant cells in terms of aggressiveness and phenotype [32]. This may further promote the selection of the most effective treatment and the creation of truly tailored therapy regimes.

The limitations of this work must be considered. The study population was relatively small, which may influence the interpretation of the results. However, small welldesigned studies are of great value as they can provide results quickly and can thus become part of a first selection in order to design further, larger confirmatory studies.

In conclusion, our results suggest that in addition to the current prognostic methods for pancreatic cancer, CTC analysis represents a potential complementary tool for prediction of patient outcome and may ultimately enable the creation of tailored therapy and improved patient care.

\section{Disclosure Statement}

All the authors declare that they have no conflict of interests.

$\begin{array}{ll}\text { References } & \text { Jemal A, Siegel R, Ward E, Murray T, Xu J, } \\ & \text { Thun MJ: Cancer statistics, 2007. CA Cancer } \\ & \text { J Clin 2007;57:43-66. } \\ & \text { 2 Jemal A, Siegel R, Ward E, Hao Y, Xu J, Thun } \\ & \text { MJ: Cancer statistics, 2009. CA Cancer J Clin } \\ & \text { 2009;59:225-249. } \\ 3 & \text { Roy LD, Sahraei M, Subramani DB, Besmer } \\ & \text { D, Nath S, Tinder TL, et al: MUC1 enhances } \\ & \text { invasiveness of pancreatic cancer cells by in- } \\ & \text { ducing epithelial to mesenchymal transition. } \\ & \text { Oncogene 2011;30:1449-1459. }\end{array}$

Oncology 2012;82:3-10 
4 Ishizone S, Yamauchi K, Kawa S, Suzuki T, Shimizu F, Harada O, et al: Clinical utility of quantitative RT-PCR targeted to alpha1,4-Nacetylglucosaminyltransferase mRNA for detection of pancreatic cancer. Cancer Sci 2006;97:119-126.

5 Riethdorf S, Fritsche H, Müller V, Rau T, Schindlbeck C, Rack B, et al: Detection of circulating tumor cells in peripheral blood of patients with metastatic breast cancer: a validation study of the CellSearch system. Clin Cancer Res 2007;13:920-928.

6 Cristofanilli M, Budd GT, Ellis MJ, Stopeck A, Matera J, Miller MC, et al: Circulating tumor cells, disease progression, and survival in metastatic breast cancer. N Engl J Med 2004;351:781-791.

7 Budd GT, Cristofanilli M, Ellis MJ, Stopeck A, Borden E, Miller MC, et al: Circulating tumor cells versus imaging - predicting overall survival in metastatic breast cancer. Clin Cancer Res 2006;12:6403-6409.

8 Cohen SJ, Punt CJA, Iannotti N, Saidman BH, Sabbath KD, Gabrail NY, et al: Relationship of circulating tumor cells to tumor response, progression-free survival, and overall survival in patients with metastatic colorectal cancer. J Clin Oncol 2008;26: 3213-3221.

9 Cohen SJ, Punt CJA, Iannotti N, Saidman BH, Sabbath KD, Gabrail NY, et al: Prognostic significance of circulating tumor cells in patients with metastatic colorectal cancer. Ann Oncol 2009;20:1223-1229.

10 Scher HI, Jia X, de Bono JS, Fleisher M, Pienta KJ, Raghavan D, et al: Circulating tumour cells as prognostic markers in progressive, castration-resistant prostate cancer: a reanalysis of IMMC38 trial data. Lancet Oncol 2009; 10:233-239.

11 Panteleakou Z, Lembessis P, Sourla A, Pissimissis N, Polyzos A, Deliveliotis C, et al: Detection of circulating tumor cells in prostate cancer patients: methodological pitfalls and clinical relevance. Mol Med 2009;15: 101-114.

12 Bidard FC, Ferrand FR, Huguet F, Hammel P, Louvet C, Malka D, et al: Disseminated and circulating tumor cells in gastrointestinal oncology. Crit Rev Oncol Hematol 2011, E-pub ahead of print.
13 Eisenhauer EA, Therasse P, Bogaerts J, Schwartz LH, Sargent D, Ford R, et al: New response evaluation criteria in solid tumours: revised RECIST guideline (version 1.1). Eur J Cancer 2009;45:228-247.

14 Bustin SA, Benes V, Garson JA, Hellemans J, Huggett J, Kubista M, et al: The MIQE guidelines: minimum information for publication of quantitative real-time PCR experiments. Clin Chem 2009;55:611-622.

15 Caraguel CGB, Stryhn H, Gagné N, Dohoo IR, Hammell KL: Selection of a cutoff value for real-time polymerase chain reaction results to fit a diagnostic purpose: analytical and epidemiologic approaches. J Vet Diagn Invest 2011;23:2-15.

16 Martin EW Jr, James KK, Hurtubise PE, Catalano P, Minton JP: The use of CEA as an early indicator for gastrointestinal tumor recurrence and second-look procedures. Cancer 1977;39:440-446.

17 Glenn J, Steinberg WM, Kurtzman SH, Steinberg SM, Sindelar WF: Evaluation of the utility of a radioimmunoassay for serum CA 19-9 levels in patients before and after treatment of carcinoma of the pancreas. J Clin Oncol 1988;6:462-468.

18 Harmenberg U, Wahren B, Wiechel KL: Tumor markers carbohydrate antigens CA 19-9 and CA-50 and carcinoembryonic antigen in pancreatic cancer and benign diseases of the pancreatobiliary tract. Cancer Res 1988;48 1985-1988.

19 Bluemke DA, Abrams RA, Yeo CJ, Cameron JL, Fishman EK: Recurrent pancreatic adenocarcinoma: spiral CT evaluation following the Whipple procedure. Radiographics 1997; 17:303-313.

20 Heiken JP, Balfe DM, Picus D, Scharp DW: Radical pancreatectomy: postoperative evaluation by CT. Radiology 1984;153:211-215.

21 Takeuchi H, Kitagawa Y: Circulating tumor cells in gastrointestinal cancer. J Hepatobiliary Pancreat Sci 2010;17:577-582.

22 Vogel I, Kalthoff H, Henne-Bruns D, Kremer B: Detection and prognostic impact of disseminated tumor cells in pancreatic carcinoma. Pancreatology 2002;2:79-88.
23 Hoffmann K, Kerner C, Wilfert W, Mueller M, Thiery J, Hauss J, et al: Detection of disseminated pancreatic cells by amplification of cytokeratin-19 with quantitative RT-PCR in blood, bone marrow and peritoneal lavage of pancreatic carcinoma patients. World J Gastroenterol 2007;13:257-263.

24 Nagrath S, Sequist LV, Maheswaran S, Bell DW, Irimia D, Ulkus L, et al: Isolation of rare circulating tumour cells in cancer patients by microchip technology. Nature 2007;450: 1235-1239.

25 Soeth E, Grigoleit U, Moellmann B, Röder C, Schniewind B, Kremer B, et al: Detection of tumor cell dissemination in pancreatic ductal carcinoma patients by CK 20 RT-PCR indicates poor survival. J Cancer Res Clin Oncol 2005;131:669-676.

26 Zhou J, Hu L, Yu Z, Zheng J, Yang D, Bouvet M, Hoffman RM: Marker expression in circulating cancer cells of pancreatic cancer patients. J Surg Res 2011;171:631-636.

27 Sergeant G, Roskams T, van Pelt J, Houtmeyers F, Aerts R, Topal B: Perioperative cancer cell dissemination detected with a real-time RT-PCR assay for EpCAM is not associated with worse prognosis in pancreatic ductal adenocarcinoma. BMC Cancer 2011;11:47.

28 Went PT, Lugli A, Meier S, Bundi M, Mirlacher M, Sauter G, et al: Frequent EpCam protein expression in human carcinomas. Hum Pathol 2004;35:122-128.

29 Tai K-Y, Shiah S-G, Shieh Y-S, Kao Y-R, Chi C-Y, Huang E, et al: DNA methylation and histone modification regulate silencing of epithelial cell adhesion molecule for tumor invasion and progression. Oncogene 2007; 26:3989-3997.

30 Spizzo G, Went P, Dirnhofer S, Obrist P, Simon R, Spichtin H, et al: High Ep-CAM expression is associated with poor prognosis in node-positive breast cancer. Breast Cancer Res Treat 2004;86:207-213.

31 Koyanagi K, Bilchik AJ, Saha S, Turner RR, Wiese D, McCarter M, et al: Prognostic relevance of occult nodal micrometastases and circulating tumor cells in colorectal cancer in a prospective multicenter trial. Clin Cancer Res 2008;14:7391-7396.

32 Mocellin S, Keilholz U, Rossi CR, Nitti D: Circulating tumor cells: the 'leukemic phase' of solid cancers. Trends Mol Med 2006;12: 130-139. 